\title{
Isolation And Identification of Cyanobacteria from Selected Caves of Bulabog Putian National Park Dingle, Iloilo, Western Visayas, Philippines
}

\author{
Mary Lou C. Arabaca ${ }^{1,2 *}$, Noel D. Roble ${ }^{3}$, Jenelle Mae B. Sanchez ${ }^{4}$ \\ ${ }^{1}$ Biology Department, School of Sciences, University of San Carlos, Cebu City, Philippines \\ ${ }^{2}$ Biology Department, Faculty of Biology, College of Liberal Arts, Sciences and Education, University of San \\ Agustin, Iloilo City 5000, Philippines \\ ${ }^{3}$ Graduate School, Dean College of Fisheries Technology, Cebu Technological University Carmen Campus, \\ Carmen, Cebu, Philippines \\ ${ }^{4}$ Senior High School - Basic Education Department, Faculty of Science, Technology, Engineering, and Mathe- \\ matics (STEM) Strand, University of San Agustin, Iloilo City 5000, Philippines
}

Article history:

Submission May 2021

Revised May 2021

Accepted July 2021

*Corresponding author:

E-mail: marabaca@usa.edu.ph

\begin{abstract}
Cyanobacteria are a photosynthetic, gram-negative, and diverse group of prokaryotic organisms inhabiting a wide range of habitats, including caves. This study was aimed to isolate and identify cyanobacteria in selected caves of Bulabog Putian National Park, Dingle, Iloilo, Western Visayas, Philippines. Six strains of cyanobacteria were identified based on morphology and 16S rRNA gene sequence analysis. The sequence homology search by BLAST program revealed that the closest relative of the six strains were Leptolyngbya sp. (94.62\% similarity), Calothrix sp. (97.07\% similarity), Chroococcidiopsis cubana (99.21\% similarity), Onodrimia javanensis (96.27\% similarity), Chroakolemma pellucida (94.74\% similarity), and Albertania skiophila (98.40\% similarity), belonging to Order Chroococcidiopsales, Nostocales, and Synechococcales. The phylogenetic tree revealed the taxonomic positions of the six cyanobacterial strains. Based on the results, six newly identified strains of cyanobacteria have been discovered from the caves of Bulabog Putian National Park which is the only finding reported. Further study, such as the polyphasic approach and other taxonomic characterizations, is needed to describe these new novel taxa of cyanobacteria.
\end{abstract}

Keywords: Cave, Cyanobacteria, $16 S$ rRNA

\section{Introduction}

Underexplored environments are important in providing fresh venues for discovering novel chemicals with biotechnological value. One of the environments is the subterranean ecosystem. Caves are environments that vary greatly from those found on the surface and are of great scientific interest due to having diverse microorganisms that have long evolved in stable conditions like in limestone cave of the Western Loess Plateau of China [1], and Bozana cave in Serbia [2, 3]. They are considered extreme environments due to scarcity in nutrients and oxygen level compared to the surface, and the microorganisms living here have adapted to cave habitat conditions and are generally unique [4].
Among the microorganisms usually found in caves, Cyanobacteria are receiving a tremendous deal of inte-rest due to its ability to produce novel com-pounds with antibacterial activity against gram positive and gram-negative bacteria [5], fungi [6], and cancer cells [7]. They are the most diverse and ubiquitous group of bacteria, thriving in both terrestrial and aquatic ecosystems and can adapt to different habitats such as [8], rock surface [9], marine water [10], and in extreme environments like hot springs [11], Arctic oceans [12], desert soil [13, 14], and caves [15]. Caves are considered to be a unique environment for cyanobacteria to grow since they have a meager amount of weather unpredictability and exposure

\section{How to cite:}

Arabaca MLC, Roble ND, Sanchez JMB (2022) Isolation and Identification of Cyanobacteria from Selected Caves of Bulabog Putian National Park Dingle, Iloilo, Western Visayas, Philippines. Journal of Tropical Life Science 12 (1): 91 - 100. doi: 10.11594/jtls.12.01.09. 
to sunlight [16]. In addition, most cyanobacteria are photoautotroph present in cave entrances directly or indirectly hit by sunlight [17]. Some are heterotroph, making them survive a prolonged dark environment [18]. It is note-worthy that cyanobacteria can adapt to the cave environment by interacting with minerals and some of the processes that reshape the caves' structure, such as the formation of speleothems like stalactites and stalagmites [19]. Furthermore, these organisms and cave habitats are rela-tively under-studied and insufficiently investigated [20]. Having to survive in a harsh environment, cyanobacteria produce a variety of secondary metabolites that enable them to survive in different environments [21].

Cyanobacteria or blue-green algae have been primarily studied based on their morphology as prokaryotic organisms [8, 22, 23]. Cyanobacterial species were recognized baased on phenotypic criteria such as cell morphology, sheath characteristics or cell ultrastructure [11]. Morphological analyses of species continue to be extremely important in Cyanobacterial diversity studies, serving as the foundation for preliminary investi-gation and avoiding difficulties in identification. Investigating different morphologies of the cyano-bacterial genus can add more knowledge about the morphological variations among the groups. This in turn, can be used as a basis for taxon identifica-tion and separation. Recently, cyanobacteria were identified and categorized using different morphological characteristics like cell dimensions, shape, color, type of branching, sheath characteristics, and cell contents [24, 25, 26]. These criteria were based on the literature published by Komarek and Anagnostids 1998 and 2005, and Komarek 2013 [27, 28, 29]. For example, morphometric characters such as the length and width of the vegetative cell, akinete, and length and width of trichomes most variable traits were found to account for 99 percent of the overall variance among the four groups which were Anabaena, Aphanizomenon, Trichormus, and Nostoc [30]. Moreover, genus Anabaena has been identified, with uniform trichomes, absence of sheath, and presence of free or floccose or soft mucilaginous thallus and heterocysts, intercalary, and presence of spores near the heterocyst or between the heterocysts [31]. Cyanobacterial isolates at different stages of growth can be examined morphologically and described using the keys provided by Desikachary (1959) [31], Rippka et al. (1979) [32], and Bergey's Manual of Systematic Bacteriology (2001) [33]. Desert soil cyanobacteria have been investigated morphologically using various morphometric traits throughout their life cycle [14]. However, some morphological characters may display phenotypic commonality with struc-tures of other species or may change due to long culture periods [32], resulting in ambiguity in the essential identification. Classification of cyanobacteria can be resolved only by utilizing other essential criteria such as genetic, ecology, physiology, and morphology. In recent years, species have been identified or characterized utilizing morphological, molecular, and ecological data [34, 35].

For decades, cyanobacteria were identified based on their 16S rRNA [13, 14, 36], nifH, and het $R$ [37] gene sequences in addition to morphological, biochemical, and ecological analyzes. However, genetic relationships sometimes conflict with morphological classification [38]. Some morphological species and strains are not identifiable, resulting in morphological and gene-tic evaluation difficulties. This is due to the lack of a culture and long-term laboratory cultivation [30]. Thus, cyanobacterial isolates should be thoroughly studied by several morphological characters and molecular genetic markers such as the $16 \mathrm{~S}$ $r R N A$ gene. The caves in Bulabog Putian National Park feature their unique geological formations such as stalactites and stalagmites. The caves have not yet been explored by researchers in microbiology and biotechnology. Thus, this study aimed to isolate and identify Cyanobacteria in selected limestone caves of Bulabog Putian National Park, Dingle, Iloilo, Western Visayas, Philippines.

\section{Material and Methods \\ Description of sampling sites}

Bulabog Putian National Park is a protected wildlife and natural park located in the northern part of Iloilo. This is situated in the municipality of Dingle and San Enrique in Panay Island, Western Visayas, Philippines, with coordinates of $11^{\circ} 0.03^{\prime} \mathrm{N} 122^{\circ} 37^{\prime} \mathrm{E}$ (Figure 1 ), about $37 \mathrm{~km}$ away from Iloilo City. Permit to collect rock samples from the caves was acquired for this park is under the management of the Protected Area Management Board (PAMB), Department of Environment and Natural Resources (DENR) Region VI, covering an area of 854.33 hectares along a $40 \mathrm{~km}$ trail in the rainforest. The park was known for its unusual geological formations such as stalagmites and stalactites, including Moroboro and Talinab springs, which serve as supplemental water sources. It is the only limestone mountain formation in Iloilo, containing thirty-three caves with different bats and other animals such as tailless scorpion, gecko, and insects. The park is well known for 


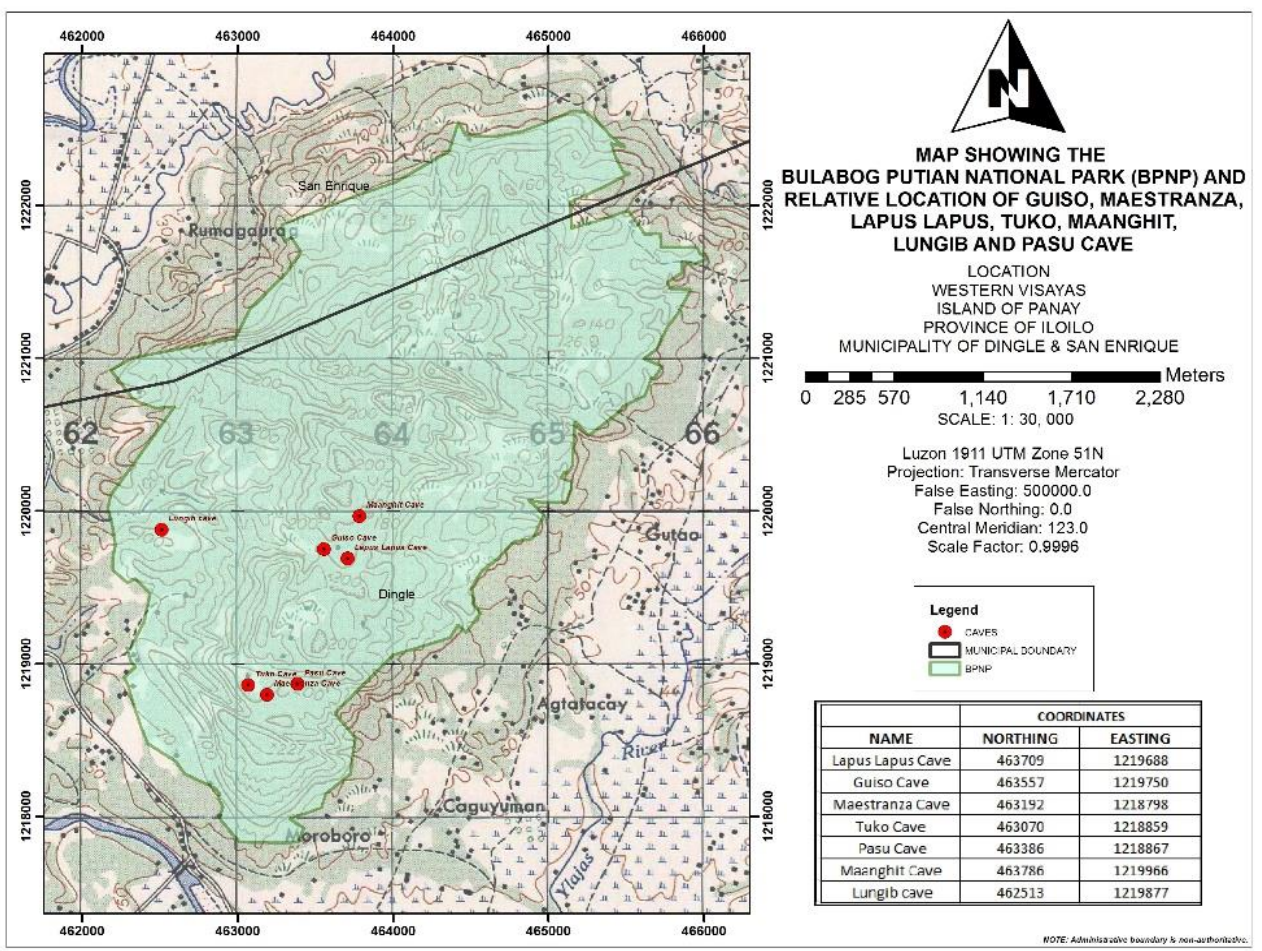

Figure 1. Collection sites of Cyanobacteria in selected caves of Bulabog Putian National Park in Dingle, Iloilo in Panay Island, Western Visayas, Philippines (image: DENR Region 6)

its forest caves with a wide diversity of flora and fauna, and researchers in microbiology and biotechnology have not yet explored the caves.

\section{Samples collection}

The collection of samples was done from May 15, 2019, to May 17, 2019. Seven caves were identified and named by the protected area management board (PAMB) of the Department of Environment and Natural Resources (DENR) Region VI was randomly selected as sampling sites. These were accessible among the caves in Bulabog Putian National Park and are good sites for cyanobacterial diversity studies due to their unique features, such as stalagmites, stalactites, lakes, and natural springs. The sampling was made in two distinguish sites in each limestone cave. One site was the physical entrance with sunlight and welloxygenated. Thus, this was called the light zone; the other site was the farther chambers illuminated only by weak natural daylight or artifi-cial light, known as the dark zone [39]. Samples were collected using a sterile scalpel and placed in sterile plastic tubes from the walls and ceilings of limestone caves with evidence of biological colonization [40]. A small quantity was scraped from the rock substrate and placed in wide-mouthed, 2 to 4 cm diameter screw-cap tubes about 10 to $20 \mathrm{~mL}$ capacity, containing a few drops of sterile water to keep the interior moist [41]. Twenty-four samples were collected in each cave, twelve from the light zone and the other twelve from the dark zone. Six subsamples were scraped from the walls about 1 to 3 feet above the cave's floor and the other six were scraped from the ceiling about 4 to 5 feet above the cave's floor under sterile conditions. Environmental variables such as light intensity (lux), temperature $\left({ }^{\circ} \mathrm{C}\right)$, and relative humidity $(\mathrm{RH} \%)$ were measured for each limestone cave. The samples were stored in a cooler without adding water for 1 hour until further treatment in the laboratory.

\section{Isolation and culture enrichment}

The materials scraped from the rock substrat of the cave with few drops of sterile water were transferred to sterile $25 \mathrm{~mL}$ test tubes containing 5 $\mathrm{ml} \mathrm{F}$ medium. After two weeks of incubation at $28^{\circ} \mathrm{C}$ under a continuous light with illumination at 3000 lux, it was transferred into another sterile 25 $\mathrm{mL}$ test tube with $10 \mathrm{~mL} \mathrm{~F}$ medium.

After three weeks of incubation at $28^{\circ} \mathrm{C}$, cyanobacterial strains were isolated by the agar plate spreading technique. One hundred microliters of cyanobacterial suspension was placed at the middle of agar-solidified F medium. Using L-shaped glass tubing, the suspension was spread out all 
throughout the solid agar F medium. The plates were incubated at $28^{\circ} \mathrm{C}$ under continuous white light at 3000 lux.

The streaking method was carried out using the $\mathrm{F}$ agar medium [24]. The plates were incubated at $28^{\circ} \mathrm{C}$ under a continuous white light with illumination at 3000 lux. The agar plates were checked regularly to monitor the growth of cyanobacterial colonies. Each colony formed was examined under a light compound microscope to confirm the presence of cyanobacterial cells and was picked up and transferred onto new agar plates with the same medium to obtain unicyano-bacterial isolates. The cells were preserved on a $25 \mathrm{~mL}$ test tube containing $\mathrm{F}$ medium and isolates were maintained under photoautotrophic condi-tions, under continuous illumination at 3000 lux and incubated at $28^{\circ} \mathrm{C}$.

\section{Cyanobacterial culture purification}

Purification of cyanobacteria was done using $200 \mathrm{mg} / \mathrm{mL}$ nystatin, $2.19 \mathrm{~mL}$ co-amoxiclav, and UV radiation, which was employed according to the method described by Garcia-Pichel et al. (1992) [42]. The isolates grown in the test tubes were exposed to UV rays for 30 minutes. The tube that showed healthy cyanobacterial growth was selected to further propagate the cultures in larger volumes [23]. The cyanobacterial strain was cultured in a $500 \mathrm{~mL}$ flask containing $150 \mathrm{~mL}$ of $\mathrm{F}$ medium without shaking. The incubation temperature was $28 \pm 2^{\circ} \mathrm{C}$ and it was illuminated at 3000 lux with a white continuous light and regime of 16 hrs light/8 hrs dark. Axenic cyanobacterial strains were maintained in the laboratory until further use.

\section{Morphological identification of cyanobacteria}

Diacritical morphological traits used in botanical species descriptions were utilized for morphological identification. For coccoid cyanobacteria, qualitative morphological characters such as the color of culture (plate or tube), color and shape of cells, presence or absence of sheath, motility, arrangement of cells or form, and quantitative morphological characters such as diameter, breadth, and length of cells were analyzed. Morphological characters such as color of culture, size and shape of vegetative cells, heterocysts, akinetes, and hormogonia, length and width of vegetative cells, color of sheath, and presence or absence of heterocysts and akinetes, were taken into analysis for filamentous cyanobacteria. Microphotograph and observations were performed using a light compound microscope equipped with digital camera Touptek wifi 1080P, and were taken in 100× objective with oil immersion. The morphometric measurements of the cyanobacteria microphotographs were carried out using image analysis software ImageJ [40]. Microphotographs were taken before morpho-metric measurements in the exponential growth phase [34], and calibration was done using software ImageJ based on the stage micrometer with $100 \times$ magnification (OIO) in the microscope. The taxonomic classification was based on morphological characteristics pre-sented in the standard classical literature [31, 32, 44, 45, 46] and in more recent taxonomic revisions [30, $47,48,49,50]$.

\section{DNA extraction, PCR amplification, and se- quencing}

Following the manufacturer's manual, the cyanobacterial DNA was extracted using PurelinkTM Genomic Plant DNA purification kit (Invitrogen/Thermo Fisher). Cyanobacterial cells were pelleted by centrifugation and was grinded using micro pestle before genomic extraction. DNA products were electrophoresed in a $1 \%$ agarose gel and checked with ethidium bromide under ultraviolet light. The resultant DNA was stored at $-20^{\circ} \mathrm{C}$ until further use.

The extracted cyanobacterial DNA was sent to Macrogen Inc., Seoul, South Korea for polymerase chain reaction (PCR) for the 16S rRNA gene using cyanobacteria-specific primers CYA359F 5'GGGGAAT (C/T)TTCCGCAATGGG$3^{\prime}$ and CYA781R 5'GACTAC (A/T)GGGGTATCTAATCCC(A/T)TT-3' [48] and for sequencing. The resulting sequences were used to confirm the identification of the cyanobacteria and for phylogenetic analysis. The consensus forward and reverse $16 \mathrm{~S}$ rRNA gene sequences obtained in the study were assembled using DNABaser software. The resulting contiguous se-quence was compared with sequence information available in the National Center for Biotechnology Information (NCBI) database using BLASTn. (http://www.ncbi.nlm.nih.gov/BLAST).

\section{Results and Discussions}

Cyanobacteria are ubiquitous, photosynthetic, and diverse groups of prokaryotic organisms. They adapt and survive to different environmental conditions including subterranean ecosystems. Caves have environments that differ significantly from those found on the surface and are considered as extreme environments due to its scarcity in nutrients and oxygen level compared to that at the surface. Despite of its habitat conditions, caves contained diverse taxa of cyanobacteria [1]. 

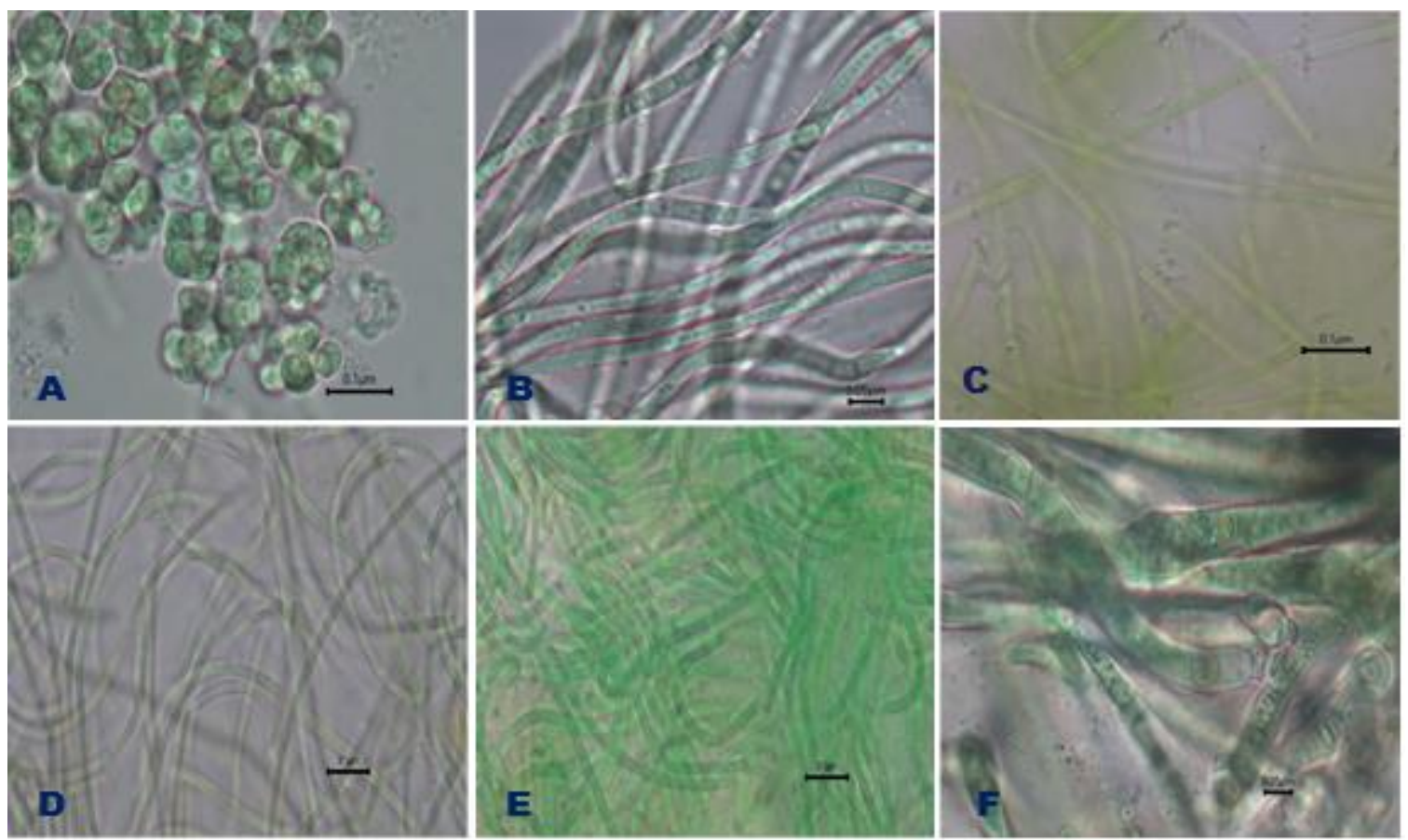

Figure 2. Microphotographs of Cyanobacterial Strains Isolated from Bulabog Putian National Park. A) Chroococcidiopsis cubana B) Leptolyngbya sp. C) Onodrimia javanensis D) Albertania skiophila E) Chroakolemma pellucida F) Calothrix sp.

Cyanobacteria can be grouped morphologically into unicellular, spherical shapes that form singly, in pairs or colony, and fila-mentous that are unbranched, false-branched or branched form [44, 45]. Based on the above mentioned morphological characterization and according to Geitler 1932 [46]; Desikachary 1959 [31]; Rippka et al. 1979 [32]; Castenholz 1989 [47]; Komarek and Anagnostids 1989 [46], and in more recent taxonomic revisions [30, 49 - 55] the present study isolated and morphologically identified six strains of cyanobacteria belonging to genera Chroococcidiopsis, Leptolyngbya, Albertania, Chroakolemma, Onodrimia, and Calothrix, and confirmed their identification based on 16S rRNA gene sequences.

The morphometric characteristics of the cyanobacteria strains are given in Table 1. Based on the available literature, CyaC9 was identified as a member of the genus Chroococcidiopsis classified as coccoid or unicellular cyanobacteria. This strain form colony, $0.08 \mu \mathrm{m}$ width and $0.10 \mu \mathrm{m}$ length with rounded cube cells having $0.03 \mu \mathrm{m}$ diameter, and dull green to bright green in color. The cells or colony are surrounded by thin, firm, colorless, and layered sheaths that allow them to stick to other filamentous cyanobacteria (Figure 2) Chroococcidiopsis usually formed an irregular colony due to impulsive multiple fission, having a different mode of division of enlarged cells. Isolates
CyaC38, CyaC24, CyaC19, and CyaC16 encompass strains that are filamentous cyanobac-teria without heterocyst, belonging to genera Leptolyngbya, Albertania, Chroakolemma, Onodrimia respectively. The trichomes are somewhat similar among the strains with width of $0.04 \mu \mathrm{m}$ and slightly attenuated at the ends (Figure 2). The vegetative cells are shorter than wide (Table 1), blue-green to olive green or bright green in color, and end cells are rounded (Figure 2). The filaments are slightly constricted at the cross walls and are distinct.

CyaC5 was a member of the genus Calothrix, the only filamentous cyanobacteria with heterocyst isolated from selected Bulabog Putian National Park and its characteristics were summarized in Table 1 . This isolate has both heterocyst which is intercalary and apical, $0.05 \mu \mathrm{m}$ width and $0.02 \mu \mathrm{m}$ length, oval and pale green in color, and akinete, $0.04 \mu \mathrm{m}$ width and $0.02 \mu \mathrm{m}$ length. The filaments are unbranched, short and slightly wide ned towards the end (Figure 2). The isolated cyanobacteria from selected caves of Bulabog Putian National Park were hard to distinguish based on its morphology because cyanobacteria can change their morphology depending on the kind of environment [56]. This is the morphological or pheno- 
Table 1. Morphological characteristics of cyanobacteria isolated from selected caves of Bulabog Putian National Park, Dingle, Iloilo, Western Visayas, Philippines. Measurements are given as mean standard deviation for $n=100$ for coccoid cyanobacteria and $n=30$ for filamentous cyanobacteria

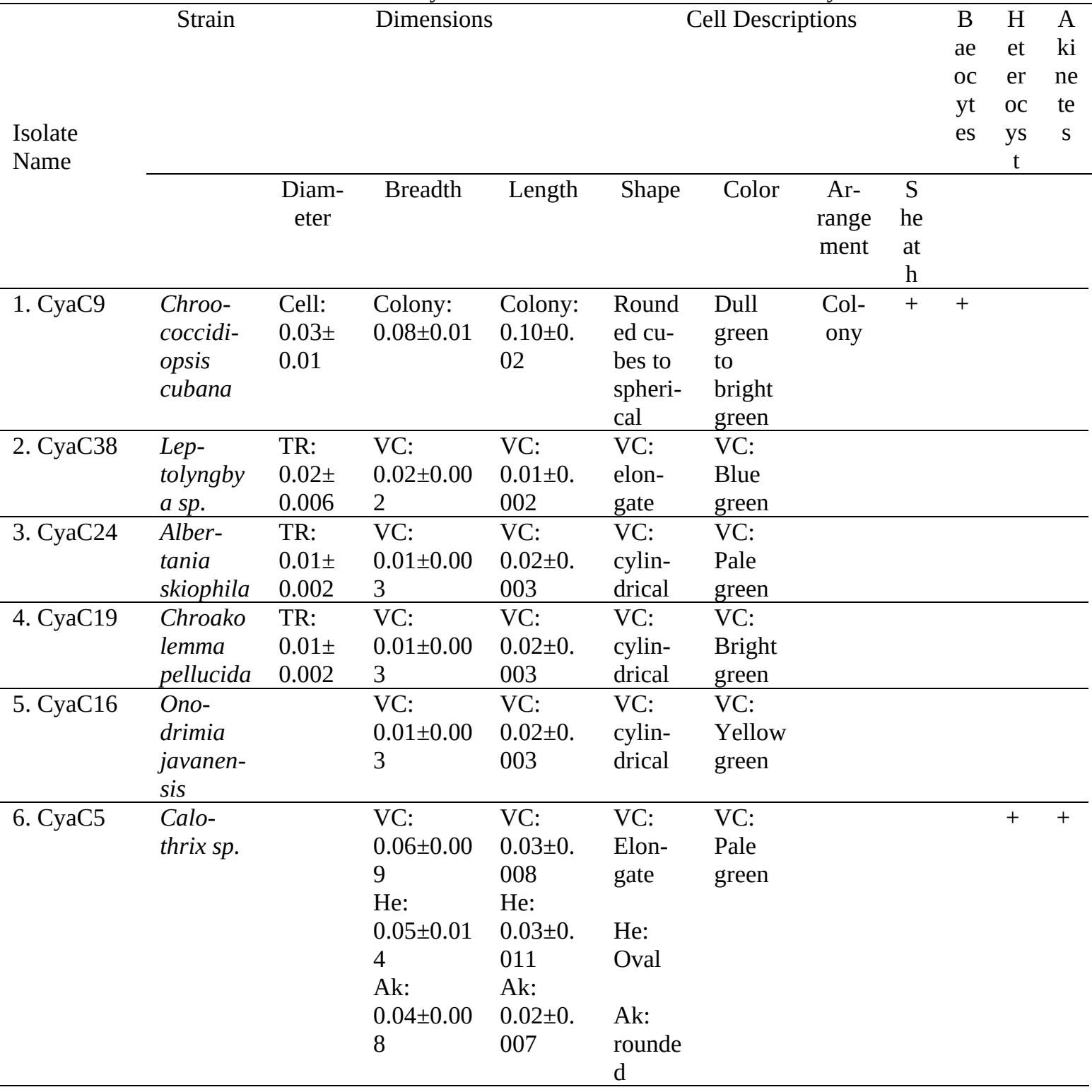

TR (trichome), VC (vegetative cell), He (Heterocyst), Ak (Akinete)

typic plasticity that makes the cyanobacterial isolates difficult to identify morphologically. The identification of cyanobacteria isolated from selected caves of Bulabog Putian National Park using molecular marker such as 16S rRNA gene was needed to confirm the identification based on morphological characters. For several years 16S rRNA sequence gene has been the pillar in the taxonomy of prokaryotes, and can measure relationships among all cyanobacterial species. The six isolated cyanobacterial strains were sub-jected to molecular analysis based on 16S rRNA gene sequence. The resulting sequences were ana-lyzed using BLAST search from NCBI website. According to DNA sequence analysis, CyaC38 was found to be similar to Leptolyngbya $s p$. (94.62\% similarity), strain CyaC5 was closely related to Calothrix sp. (97.07\% similarity), CyaC9 was Chroococcidiopsis cubana (99.21\% similarity), CyaC16 was Onodrimia javanensis (96.27\% similarity), CyaC19 was Chroakolemma pellucida (94.74\% similarity), and CyaC24 was Albertania skiophila (98.40\% similarity).

The BLASTn result analysis based on 16S 


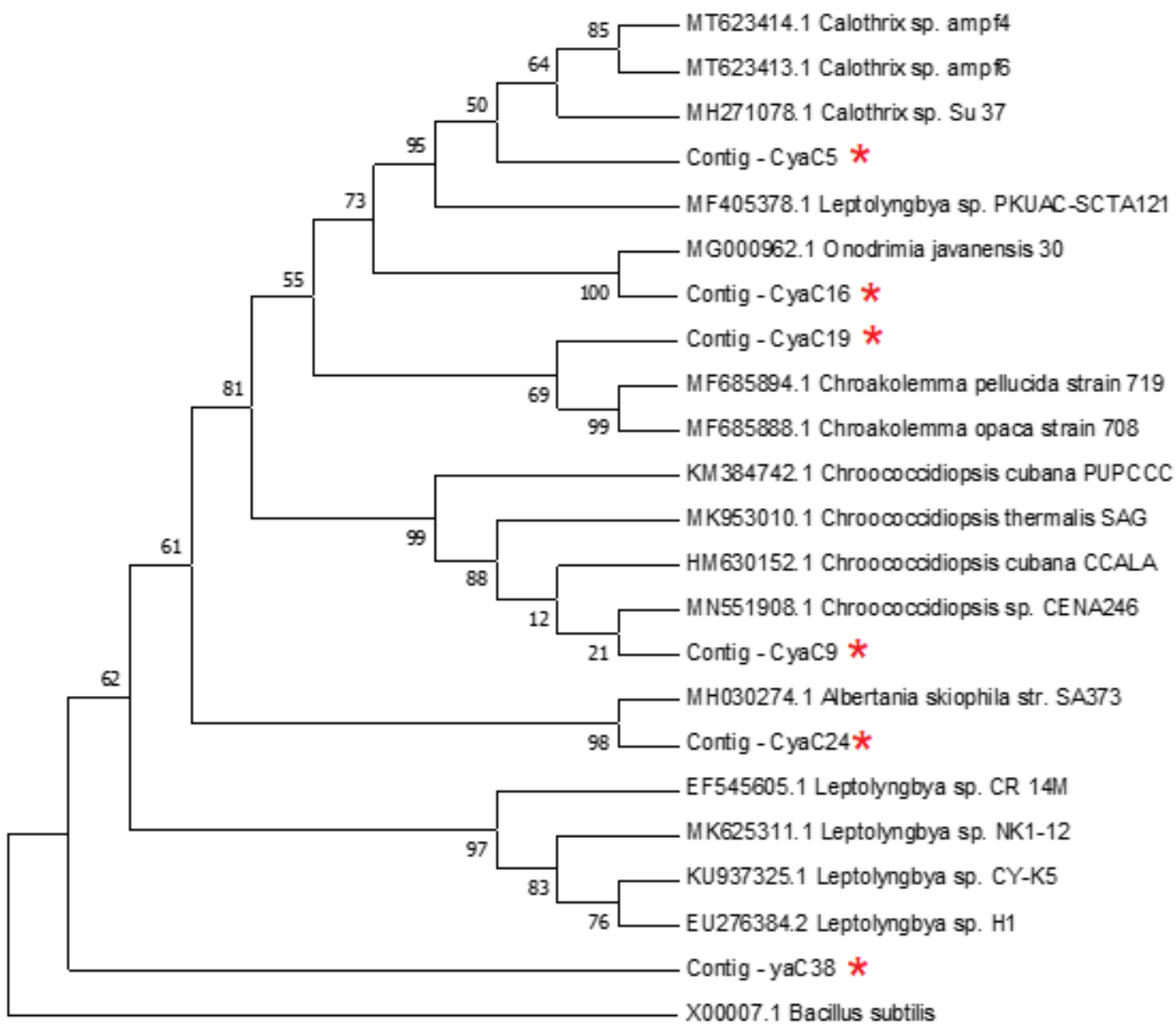

Figure 3. Phylogenetic position of the six cyanobacterial strains isolated from selected cave of Bulabog Putian National Park based on 16S rRNA gene sequences data. Phylogenetic tree was constructed using Maximum Likelihood method, 1000 bootstrap replications with Bacillus subtilis as outgroup. Cyanobacterial strains of the present study is mark by a red star $(*)$

Table 2. BLAST search results of cyanobacteria strains used in this study based on 16S rRNA gene sequence analysis

\begin{tabular}{llll}
\hline Strain & Sequence Similarities & Accession No. & Identity (\% Homology) \\
\hline 1. CyaC38 & Leptolyngbya sp. HI & EU276384 & $94.62 \%$ \\
2. CyaC5 & Calothrix sp.ampf4 & MT623414 & $97.07 \%$ \\
3. CyaC9 & Chroococcidiopsis cubana SAG 39.79 & MK484708 & $99.21 \%$ \\
4. CyaC16 & Onodrimia javanensis 30 & MG000962 & $96.27 \%$ \\
5. CyaC19 & Chroakolemma pellucida strain 719 & MF685887 & $94.18 \%$ \\
6. CyaC24 & Albertania skiophila str. SA 373 & MH030274 & $98.40 \%$ \\
\hline
\end{tabular}

rRNA supports the morphological identification of the cyanobacteria isolates from Bulabog Putian National Park. Nevertheless, three cyanobacteria strains Leptolyngbya sp., Chroakolemma pellucida, and Onodrimia javanensis have the low percentage similarity of their $16 \mathrm{~S}$ rRNA sequence data (> 97\%) to its closest related taxon, showing that they were genetically different from its closest related taxon, thus can be a new strain of the same species. However, BLASTn result having less than $97 \%$ similarity to existing known species in the NCBI database would be only indicative of a new strain to that species, not prospective new species of itself [57]. To determine an isolate as new taxa, several analyses should be taken into account other than morphology and 16S rRNA 
gene analysis. The low percentage similarity of its 16S rRNA is congruent to the results of the previous studies on cyanobacteria identification based on 16S rRNA gene with percentage similarity ranging between $92.5 \%$ and $99.7 \%$ [38, 58, 59]. Based on morpho-logical and molecular analysis, the cyanobac-teria isolated from selected caves of Bulabog Putian National Park belong to Order Chroococcidiopsales (Chroococcidiopsis), Nostocales (Calothrix), and Synechococcales (Leptolyngbya, Albertania, Onodrimia, Chroakolemma). Figure 3 showed the phylogenetic position of the six strains among the closely related cyanobacteria. The phylogenetic tree revealed and confirmed that the cyanobacterial strains from selected caves of Bulabog Putian National Park, Dingle, Iloilo, Western Visayas, Philippines were distinct to their closest related taxon.

\section{Conclusion}

This study isolated and identified six cyanobacterial strains attained from selected caves of Bulabog Putian National Park, Dingle, Iloilo, Western Visayas, Philippines. The strains were successfully identified based on morphology and 16S rRNA gene sequence data analysis. The closest related taxa to the six strains were Leptolyngbya sp., Calothrix sp., Chroococcidiopsis cubana, Onodrimia javanensis, Chroakolemma pellucida, and Albertania skiophila, as determined by $16 \mathrm{~S}$ rRNA gene sequence analysis using the BLAST search program.

Six strains of cyanobacteria have been identified belonging to the Orders Chroococcidiopsales (Chroococcidiopsis), Nostocales (Calothrix), and Synechococcales (Leptolyngbya, Albertania, Onodrimia, Chroakolemma) which normally present in extreme environments such as the caves in Bulabog Putian National Park. Addi-tional research, such as a polyphasic approach and other taxonomic characterization, is required to fully describe these novel cyanobacteria taxa.

\section{Acknowledgement}

The authors are grateful to Protected Area Management Board (PAMB) of the Department of Environment and Natural Resources (DENR) Region 6 for the permit to collect samples from the caves. Authors also acknowledge the Biology Laboratory, University of San Agustin for the facilities. This study was supported by grants from the
Commission on Higher Education (CHED) as graduate scholarship.

\section{References}

1. Popovic S, Simic GS, Stupar M et al (2015) Cyanobacteria, algae and microfungi present in biofilm from Bozana Cave (Serbia). International Journal of Speleology 44 (2): 141-149.

2. $\mathrm{Wu} \mathrm{Y,} \mathrm{Tan} \mathrm{L,} \mathrm{Llu} \mathrm{W} \mathrm{et} \mathrm{al.} \mathrm{(2015)} \mathrm{Profiling} \mathrm{bacterial} \mathrm{di-}$ versity in a limestone cave of the western Loess Plateau of China. Frontiers in Microbiology 6(244).

3. Axenov-Gribanov DV, Voyteskhovskaya IV, Tokovenko BT et al. (2016) Actinobacteria Isolated from an underground Lake and Moonmilk Speleotherm from the Biggest Conglomerate Karstic Cave in Siberia as Sources of Novel Biological Active Compounds. PLOS ONE 11(3): e0152957 doi: 10.1371/journal.pone.0152957

4. Candiroglu B, Gungor ND (2017) Cave Ecosystems: Microbiological View European Journal of Biology 76 (1): 36-42 doi: 10.5152/EurJBiol.2017.1707

5. Malathi T, Babu MR, Mounika T et al. (2014) Screening of cyanobacterial strains for antibacterial activity International Journal of Advanced Life Sciences 7 (3). doi: 10.1.1.1053.2344\&rep=rep1\&type=pdf

6. Tyagi R, Kaushik BD, Kumar J (2014) Antimicrobial Activity of Some Cyanobacteria. Microbial Diversity and Biotechnology in Food Security. DOI 10.1007/97881-322-1801-2_41.

7. Raja R, Hemaiswarya S, Ganesan V, Carvalho IS (2016) Recent developments in therapeutic applications of Cyanobacteria Critical Reviews in Microbiology 42 (3): 394-405. doi: 10.3109/1040841X.2014.957640

8. Soltani N, Zarrini G, Ghasemi Y et al. (2007) Characterization of a Soil Cyanobacterium Fischerella sp. FS 18 under $\mathrm{NaCl}$ Stress Journal of Biological Sciences 7(6):931-936

9. Hauer T, Muhlsteinova R, Bohunicka M et al. (2015) Diversity of Cyanobacteria on rock surfaces Biodiversity Conservation 24: 759-779. doi: 10.1007/s10531-0150890-z

10. Moss NA, Leao T, Glukhov E et al. (2018) Collection, culturing, and genome analyses of tropical marine filamentous benthic cyanobacteria. Methods of Enzymology Volume 604: 3-43. doi: 10.1016/bs.mie.2018.02.014.

11. Jahadarova E, Dvorak P, Hasler P, Poulickova A (2017) Revealing hidden diversity among tropical cyanobacteria: the new genus Onodrimia (Synechococcales, Cyanobacteria) described using polyphasic approach. Phytotaxa 326 (1): 28-40. doi: 10.11646/phytotaxa.326.1.2

12. Taton A (2006) Polyphasic study of Antarctic Cyanobacterial Strains. Journal of Phycology 42: 12571261.

13. Garcia-Pichel F, Lopez-Cortes A, Nubel U (2001) Phylogenetic and morphological diversity of cyanobacteria in soil desert crusts from the Colorado Plateau. Applied and Environmental Microbiology. 67 (4): 1902-1910.

14. Rehakova K, Joahansen JR, Casamatta DA et al. (2007) Morphological and molecular characterization of selected desert soil cyanobacteria: three species new to 
science including Mojavia pulchra gen. et sp. nov. Phycologia 46 (4).

15. Lamprinou V, Skaraki K, Kotoulas G et al. (2012) Toxopsiscalypsus gen.nov., sp.nov. (Cyanobacteria, Nostocales) from cave "Francthi”, Peloponnese, Greece: a morphological and molecular evaluation. International Journal of Systematic and Evolutional Microbiology 62: 2870-2877.

16. Dayner D, Johansen J (1991) Observations on the algal flora of Seneca Cavern, Seneca Country, Ohio. Ohio Journal of Science 91:118-121.

17. Mulec J, Kosi G. 2008. Algae in the aerophytic habitat of Raciske ponikve cave (Slovenia). Natura Sloveniae 10 (1): 39-49.

18. Sarma AP, Haseena PP, Ul-Hasan MA, Basha KS (2014) Life threatening effects of ultraviolet $-B$ radiation on the cyanobacteria. Biochemical and Cellular Archives 10 (1): 154-169.

19. Barton HA, Jurado V (2007) What's up down there? Microbial diversity in caves. Microbe 2:132-138.

20. Miscoe LH, Johansen JR, Kociolek JP et al. (2016) Novel Cyanobacteria from caves on Kauai, Hawaii. Bibliotheca Phycologia 120: 75-152.

21. Babic O, Kovac D, Raseta M et al. (2015) Evaluation of antioxidant activity and phenolic profile of filamentous terrestrial cyanobacterial strains isolated from forest ecosystem. Journal of Applied Phycology 28:2333-2342. doi: 10.1007/s10811-015-0773-4

22. Hoffmann L, Gugger M (2003) Morphological and molecular characterization of a stigonematalean cyanobacterium isolated from a Spanish cave Algological Studies 109 (4):259-265.

23. Lamprinou V, Skaraki K, Kotoulas G et al. (2013) A new species of Phormidium (Cyanobacteria, Oscillatoriales) from three Greek Caves: morphological and molecular analysis. Fundamental Applied Limnology 182 (2):109116.

24. Salem SH, El-Zamik FI, Howaida ML et al. (2011) Isolationand identification of some indigenous cyanoprokaryota isolates based on morphological and physiological characterizations. Egyptian Journal of Phycology 12 (1): 13-32

25. Pramannik A, Sundararaman M, Das S et al. (2011) Isolation and characterization of cyamobacterial possessing antimicrobial activity from the Sudarbans, the world's largest tidal mangrove forest. Journal of Phycology 47: 731 - 743.

26. Dvorak P, Casamatta DA, Hasler P et al. (2017) Diversity of the cyanobacteria. Modern topics in the phototrophic prokaryotes. doi: 10.1007/978-3-31946261-5_1.

27. Komarek J, Anagnostids K (1998) Cyanoprokaryota. 1. Teil. Chroococcales. In Gartner, EH, Heynig H, Mollenhauer D. [Eds.] Su“ßwasserflora von Mitteleuropa. Gustav Fischer, Jena, Germany, pp. 1548.

28. Komarek, J, Anagnostidis K (2005) Cyanoprokaryota. 2. Teil. Oscillatoriales. In Bu“ del, B., Krienitz, L., Ga“rtner, G. \& Schagerl, M. [Eds.] Su“ßwasserflora von Mitteleuropa. Elsevier Spektrum, Heidelberg, Germany, pp. 1-759.

29. Koma'rek J, Sant'Anna C, Bohunicka' M et al. (2013) Phenotype diversity and phylogeny of selected Scytonema-species (Cyanoprokaryota from SE
Brazil). Fottea 13:173-200

30. Rajaniemi P, Hrouzek P, Kastovska K et al. (2005) Phylogenetic and morphological evaluation of the genera Anabaena, Aphanizomenon, Trichormus and Nostoc (Nostocales, Cyanobacteria). International Journal of Systematic and Evolutionary Microbiology 55:11-26.

31. Desikachary TV (1959) Cyanophyta. Indian Council of Agricultural Research. New Delhi, India.

32. Rippka R, Deruelles J, Waterbury J et al. (1979) Generic assignments, strain histories and properties of pure cultures of cyanobacteria. Journal of General Microbiology 111: 1-61.

33. Bergey's Manual of Systematic Bacteriology, 2nd edn. Springer: New York.

34. Lamprinou V, Skaraki K, Kotoulas G et al. (2012) Toxopsis calypsus gen.nov., sp.nov. (Cyanobacteria, Nostocales) from cave "Francthi", Peloponnese, Greece: a morphological and molecular evaluation. International Journal of Systematic and Evolutional Microbiology 62: 2870 - 2877.

35. Ananya, Kamal A, Ahmad IZ (2014) Cyanobacteria "the blue algae" and its novel application: A brief review. International Journal of Innovation and Applied Studies. 7 (1): $251-261$.

36. Hoffmann L, Gugger M, Asencio A. 2003. Morphological and molecular characterization of a Stigonematalean cyanobacterium isolated from Spanish cave. Algol Studies. 109:259-265.

37. Galhano V, de Figueiredo DR, Alves A et al. (2011) Morphological, biochemical and molecular characterization of Anabaena, Aphanizomenon and Nostoc strains (Cyanobacteria, Nostocales) isolated from Portuguese freshwater habitats. Hydrobiologia 663: 187203.

38. Silva CSP, Genuario DB, Vaz MGMV, Fiore MF (2014) Phylogeny of culturable cyanobacteria from Brazilian mangroves. Systematic and Applied Microbiology 37 (2):100-12. doi: 10.1016/j.syapm.2013.12.003.

39. Czerwik-Marcinkowska J, Mrozinska T (2011) Algae and Cyanobacteria in Caves of the Polish Jura. Polish Botanical Journal 56 (2): 203 - 243.

40. Czerwik-Marcinkowska J, Massalski A (2018) Diversity of Cyanobacteria on Limestone Caves. Doi: 10.5772/intechopen.79750.

41. Rippka R (1988) Isolation and purification of cyanobacteria. Methods Enzymology 167: 3-27.

42. Garcia-Pichel F, Sherry ND, Castenholz RW (1992) Evidence for an ultraviolet sunscreen role of the extracellular pigment scytenemin in the terrestrial cyanobacterium Chiorogloeopsis sp. Photochemistry and Photobiology 56(1): 17-23.

43. Rasband WS. ImajeJ, U.S. National Institutes of Health, Bethesda, Maryland, USA. http://imagej.nih.gov/ij/, 1997-2018.

44. Stocks HS. 2013. A survey of the Taxonomy of the Cyanobacteria from Northeast Florida, Descriptions of Novel taxa, and an Investigation into the Factors which influencethe Epibenthic Cyanobacterial Community. UNF Graduate theses and Dissertations. 480.

45. Amarawansa RPUI, Balasooriya BLWK, Dandeniya WS, Suganthan B, Dasanyaka T. 2018. Identification of cyanobacteria inhabiting paddy fields in intermediate zone and dry zone of Sri Lanka. Tropical Agricultural 
Research. 29 (4):420-429.

46. Geitler L (1932) Cyanophyceae. In Kolkwitz R (ed.), Rabenhorst's Kriptogamenflora von Deutschland, O "sterreich und der Schweiz. Akademische Verlagsgesellschaft, Leipzig, Federal Republic of Germany. Pp. 1-1196.

47. Castenholz RW (1989) Subsection IV. Order Nostocales. In Staley, JT, Bryant MP, Pfenning $\mathrm{N}$ and Holt JG (eds), Bergey's Manual of Systematic Bacteriology, Volume 3. Williams and Wilkins, Baltimore. Pp. 17801793.

48. Komarek J, Anagnostids K (1989) Modern approach to the classification system of Cyanophytes,4:

Nostocales, Archive fur Hydrobiologie Supplement/Algalogical Studies 82 (56):247-345.

49. Komárek J, Komárková J (2003) Phenotype diversity of the cyanoprokaryotic genus Cylindrospermopsis (Nostocales). Czech Phycology 3: 1-30.

50. Willame R, Boutte C, Grubisic S et al. (2006) Morphological and molecular characterization of planktonic cyanobacteria from Belgium and Luxembourg. Journal of Phycology 42: 1312-1332.

51. Komarek J (2010) Modern taxonomic revision of planktic nostocacean cyanobacteria: a short review of genera. Hydrobiologia 639:231-243.

52. Gama Jr. AW, Laughinghouse IV HD, Sant'Anna CL (2014) How diverse are coccoid cyanobacteria? A case study of terrestrial habitats from the Atlantic Rainforest (Sao Paulo, Brazil). Phylotaxa 178 (2): 061-097. doi: 10.11646/phylotaxa

53. Komárek J, Kaštovský J, Mareš J, Johansen JR (2014) Taxonomic classification of cyanoprokaryotes (cyanobacterial genera) 2014, using a polyphasic approach. Preslia 86: 295-335.

54. Komárek J, Komárková J (2004) Taxonomic review of the cyanoprokaryotic genera Planktothrix and Planktothricoides. Czech Phycology 4: 1-18.

55. Komárek J (2014) Modern classification of Cyanobacteria. In : Sharma NK et al. (Eds.), Cyanobacteria - an economic perspective. Willey Blackwell. Pp 21-39.

56. Prihantini NB, Sjamsuridzal W, Yokota A (2018) Characterization of culturable cyanobacteria isolated from Geyser of Cisolok in West Java, Indonesia AIP Conference proceedings 2023, 020135 doi: 10.1063/1.5064132.

57. Ojo KS (2014) What is the minimum percentage of identity required by BLAST to tentatively determine new species of Bacteria

58. Myers L, Sekar R, Laurie L (2007) Molecular detection and ecological significance of the Cyanobacterial genera Geitlerinema and Leptolyngbya in Black Band Disease of Corals. Applied and environmental microbiology 73.

59. Siels K, Browne N, Donovan F (2019) Molecular characterization of twenty-five marine cyanobacteria isolated from Coastal Regions of Ireland. Biology (Basel) 8 (3):59. 